\title{
Parents in Exile: Challenges of Parenting among Refugees and Asylum Seekers in Bulgaria
}

\author{
ALMA PEZEROVIĆ * \\ Save the Children International \\ Hrvatska
}

MARINA MILIĆ BABIĆ

Studijski centar socijalnog rada

Pravni fakultet Sveučilišta u Zagrebu

Zagreb, Hrvatska

\author{
Original Scientific Paper \\ UDK: 325.25-054.73-055.52(497.2) \\ doi: $10.3935 /$ rsp.v26i1.1478 \\ Received: June, 2017.
}

\section{SELMA POROBIĆ}

Palacký University Olomouc

Olomouc, Czech Republic

Purpose: This paper looked into the experiences of refugee parents with an aim to uncover the challenges of parenting encountered during and after the asylum procedures in Bulgaria - a country placed at the bottom of the asylum recognition scale in Europe. Methods: Qualitative research through semi-structured interviews of eight parents originating from Iraq, Syria and Palestine was conducted during the 3 months' period in 2016. Results: Empiric research conducted revealed that procedural shortcomings of refugee protection system in Bulgaria causes severe psychosocial stresses to families in that the factors, such as slow and deficient asylum procedures, inadequate social protection and absence of integration programs, have a direct impact on the family life, parenting and children's wellbeing. Discussion: These results point to a clear need for improvement of the access to asylum right and subsequent refugee integration in Bulgaria. They also call for a systemic approach in which the refugee rights are fully respected and vulnerability inherent to the refugee parents' liminal position properly addressed. We further recommend the interventions of social work and mental health professions in ameliorating existent stresses of exclusion and marginalisation of refugee families with an aim to advance their full integration rights.

Keywords: refugee protection, asylum right, integration, refugee families, parenting in exile, psychosocial support

\footnotetext{
*Alma Pezerović, Save the Children International, pezerovic.alma@yahoo.com
} 


\section{INTRODUCTION}

\section{Background}

The current figures illustrate a distressing trend of wars and persecutions across the globe forcing some 65.3 million people to flee their homes. Among these, 21.3 million are refugees, with half of that population being children and minors. Only from September 2015 to January 2016 more than one million people, mostly from Syria, Iraq and Afghanistan, came to Europe to seek safety and protection (EU Committee, 2016). In early 2016, it was estimated that more than 50 per cent of all refugees and migrants arriving to Europe were women and children, with over a third of them children (UNHCR, 2016b).

The term refugee as a legal term stemming from Refugee Convention refers to "any person who, owing to well-founded fear of being persecuted for reasons of race, religion, nationality, membership of a particular social group or political opinion, is outside the country of his nationality and is unable or, owing to such fear, is unwilling to avail himself of the protection of that country"1. Accordingly, the international protection implies that in circumstances defined by Convention it is another (signatory) state's obligation to grant protection to the applicants of asylum on its own territory. However, it is a low probability to be recognised as a convention refugee in $\mathrm{EU}$ today and to be granted the full protection. More asylum seekers are granted complementary forms of protection like subsidiary protection. ${ }^{2}$
The number of persons seeking asylum from non-EU countries in the EU Member States during the second quarter of 2018 was 137000 , a number around the levels recorded in 2014, before the peaks of 2015 and 2016. Majority come from Syria, Afghanistan and Iraq and are registered in Germany, France, Greece and Spain. During the second quarter of 2018, of 142700 first instance decisions, only $37 \%$ were positive (i.e. granting a type of protection status). ${ }^{3}$

\section{Refugees and asylum seekers in Bulgaria}

Given the focus of this research on Bulgaria, a country-specific demographic overview of the refugee situation is introduced in this section.

It is important to note that reliable and accurate information on asylum seekers in Bulgaria is difficult to obtain, in particular the breakdown of data according to sex, age, gender, the presence of vulnerable categories, as well as the full overview of the asylum application statuses (UNHCR, 2014). The public administration is slower in comparison to other EU countries in responding to new developments on the ground, and the statistical database on the number of foreign citizens in the country is incomplete and unreliable (Hajdinak, 2011). For the same reason, UNHCR asserts that the number of people who lodged or intended to lodge their asylum application in Bulgaria is most likely higher than the official numbers presented by state.

\footnotetext{
${ }^{1}$ Article 1 of Geneva Convention relating to the Status of Refugees 1951and New York Protocol 1967.

${ }^{2}$ Refugee status is defined in Article 1 of the Geneva Convention relating to the Status of Refugees of July 1951 ,28, as amended by the New York Protocol of January 1967,31. Subsidiary protection is defined in Article 2(g) of Directive 95/2011/EC, and is granted to a person who does not qualify for refugee status, but faces risk of serious harm upon return to the country of origin. Humanitarian status is granted under national law for persons who are not eligible for international protection as defined in Directive 95/2011/EC, but who are not removed because of ill health or because they are unaccompanied minors.

${ }^{3} \mathrm{https}$ //ec.europa.eu/eurostat/statisticsexplained/index.php/Asylum_quarterly_report\#Decisions_on_asylum_applications
} 
During the largest one-time refugee influx to EU in 2015, Bulgaria was faced with 20391 asylum seekers, when the refugee status was granted to 4708 persons and subsidiary protection to another 889 persons. In 2016, out of 19418 applicants, refugee status was granted to only 764 , while subsidiary protection to 587 asylum seekers. In 2017, number of asylum seekers dropped to 3700 persons and the asylum rejection rate was $64.2 \%$. The European Economic and Social Committee (EESC) has further reported that only $30 \%$ of applicants have remained in the country for the outcome of their asylum claims and that the majority left the country before the end of the procedure (EESC, 2016) ${ }^{4}$. Finally, in the first half of the 2018, Bulgaria has had only 154 asylum applications submitted (State Agency for Refugees, 2018).

In comparison to other European countries, Bulgaria is placed at the bottom of the protection scale with the lowest asylum recognition rate of $46 \%$ (UNHCR, 2016a) Furthermore, in the course of 2015-2017 the Bulgarian authorities arrested over 50 000 persons for entering/ exiting or traveling through the country without legal documentation (Ministry of Interior, 2015; IOM, 2016). In addition, there are consistent reports of violent pushbacks at the borders, interception, denial of access to state territory and other violations of asylum right reported by NGO (Bulgarian Helsinki Committee, 2017).

On the other hand, the main impediment to effective integration of recognised refugees is the lack of the national strategy for introductory courses of Bulgarian language, cultural orientation and effective social protection despite the continued recommendations of the NGOs involved in the development of the national strate- gic documents on migration (EESC, 2016). These NGOs reported that the majority of services, including child care, remained available only to individuals who spoke Bulgarian or individuals otherwise integrated in the labour market. Moreover, the prevailing obstacles in accessing different social services often result from inadequate provision of information regarding asylum seekers and recognised refugees' rights in the country (Bulgarian Helsinki Committee, 2016; EESC, 2016).

Finally, the NGOs have also remarked on the insufficient dialogue and various impediments to full cooperation with the government on the protection programs, including the implementation of language courses and vocational training courses for refugees.

\section{Conceptual approach to parenting in exile}

Parenting is critically important to a child's health and development as it is related to the ability of parents and primary carers to ensure that the child's developmental needs are being appropriately met. Parenting also demands flexibility in responding to changing needs of the child both over time and in a variety of situational contexts. General aspects of parenting include provision of basic care, ensuring child's safety, stability, emotional warmth, stimulation, guidance, setting boundaries and other behaviours in support of promoting psychosocial, cognitive and physical growth. The relationships between a child and a parent is not a one-directional process but a complex interaction and transaction across time and in different contexts and environments influencing it. Consequently, in the literature there is little clarity on the ideal parenting and responsibilities thereof (Eve

\footnotetext{
${ }^{4}$ In 2014 , due to lengthy procedures for registration and with no official documents, accommodation or access to social welfare and health care services, large number of asylum applicants left Bulgaria in search for the country that could offer more effective protection (UNHCR, 2014; AIDA, 2015b).
} 
et al., 2014). The concept of 'good enough parenting' is often seen as subjective (Farnfield, 2008) and elusive (Taylor et al., 2009).

In this study, parenting is understood through an ecological framework (Bronfenbrenner, 1979), as to capture direct influences on the child within the microsystem (primary caregivers) but also to focus on the interrelationships between other significant members of the family and the child's surrounding (mesosystem). Such research approach allows to fully grasp the dynamic nature of relationships, which have an overall impact on the parenting by incorporating the effects of social and cultural aspects of parenting.

Through the concept of ecosystem's approach, we are allowed to examine the quality of interrelationships in the settings/systems that the person may not fully interact with, but which still significantly impact on the relationships within microsystem. Here we refer to e.g. employment, housing conditions, engagement with the community and similar. For example, the fact that refugees during the asylum procedures experience financial difficulties and dependence on the social welfare systems, can impact on parenting and child care. In this situation the minimal standard care could be seen as a good enough parenting according to White (2005). Ecological framework also takes into consideration macrofactors, e.g. policy and legislation, which influence person's well-being and therefore have relevance to refugee parents subjected to various asylum and integration policies.

\section{Research problem and objectives}

Refugees experience various adversities, which can have an impact on their parenting. Traumatic experiences affect the refugee parents on multiple levels including their psychological wellbeing, health, social relationships, professional and family roles, as well as the marital relationships (Rogers,
Floyd, Seltzer, Greenberg and Hong, 2010) Moreover, research on the link between the exposure to war and post-traumatic stress symptoms, depression, anxiety and impaired capacity to perform the activities of daily living, points to the challenges encountered in the adaptation to conditions of the receiving countries. The common challenges involve inadequate housing, poverty, social isolation, discrimination, behavioural disorders in children, and, for unregistered refugees without appropriate legal documents even the fear of deportation to the country of origin (Birman et al., 2005; Miller and Rasmussen, 2009).

The anxiety of parents also makes them more vulnerable in their ability to attend to frustrations of their children and their own sense of vulnerability (Groves and Zuckerman, 1997; Osofsky and Fenichel, 1994, 1996, 2000). For many parents, significant challenges involve also balancing the attachment to their own cultural values with the adaptation to the host culture, where the aspect of raising children in a new cultural environment acts as the additional stress in parenting (Tingvold, Hauff, Allen and Middelthon, 2012).

Furthermore, refugees frequently suffer from stresses connected to the experiences of torture, trauma, separation from their family or loss of family members. Besides this, refugee families also typically experience changes in parental roles, language barriers and different cultural expectations and behaviours (Allen, Vaage and Hauff, 2006; Fatumo, Allvin, Flacking, Schon, 2016). At the same time, literature on children affected by uprootment due to war and transitory conditions of the exile points to the critical role of the primary care givers in alleviating the negative effects of crisis through nurturing and responsive care (Murphy et al. 2017; Almquist \& Broberg, 1999; Fazel \& Stein 2002). Research on protective factors such as economic and social integration of refugee parents has 
also been identified as relevant to the future wellbeing of their children (Landale, Thomas and Van Hook, 2012). However, research on the effects of forced migration and exile at a family level, and in particular on parenting and bonds between parents and children, is still limited and deserves more attention (Kerig, 2018).

In line with this previous body of research, we aimed to investigate the effects of exile on parenting for the refugee families during and after asylum procedures in Bulgaria. To do so, we formulated the following leading research questions:

1) Which challenges are encountered by refugee parents in the host country?

2) What are their central worries and stresses?

3) How are they supported and how do they deal with these?

4) What are their future plans, hopes and aspirations?

\section{METHOD}

\section{Qualitative research design}

This research employed a qualitative research design as it aimed at investigating parenting as a social phenomenon with the underlying meaning making processes as expressed by the refugee informants in this study (Bryman, 2008). We wanted to better understand how these individuals think and feel about the parenting on the subjective level (Patton, 2002). The chosen method of data collection involved semi-structured interviews consisting of open-ended questions which enabled us to collect rich qualitative data, following a consistent structure (Galletta and Cross, 2013). The same questions were asked to all research participants (Gillham, 2005) on the basis of the interview guide comprising twelve open-ended questions, which were inspired by the theoretical framework of resilience vs vulnerability (Daniel et al, 2010; Ungar, 2008). Such an approach helped us to identify adversities (challenges, difficulties), which refugee face in Bulgaria; to account for experiences (to identify their vulnerabilities); to assess the support received (protective environmental factors) and to capture personal aspirations and hopes (positive values as one of the resilience domains). We aspired to look into the dynamic nature of the system's factors and it was important to create an atmosphere of acceptance and non-judgmental listening thus to ensure that parents did not feel under scrutiny during the interviews (Magnusson and Marecek, 2015).

Eight interviews were conducted by the first author of the paper who initiated contact with different refugee families in Bulgaria from April until June 2016. The interviews lasted from thirty to forty-five minutes on average.

As it was not possible to lead the conversations in English with all of the participants, the assistance of an interpreter was used. Interviews were then conducted in English while the interpreter was simultaneously translating to Arabic and back to English. Since the research involved participants settled in two Bulgarian cities, Sofia and Harmanli, two different interpreters were engaged in the translation of the interviews.

Most interviews were conducted in the reception centre, while some took place in the office of Caritas, where the researcher worked. Prior to the interviews, the interpreters had been briefed on the research aims and the interviewing method. Correspondingly, the participants also received information on the research objectives and provided their consent to participate in the project. They were given the option to withdraw from the interview at any point and provided their consent to the audio recording of the interviews. In addition, the participants were asked to provide their consent to the presence of interpreter in cases when 
translation assistance was necessary. The participants were guaranteed anonymity and confidentiality of the information they provided. This was ensured by not posing inquiries on the first and last names, as well as by labelling the participants in data analysis with the letters $\mathrm{M}$ or $\mathrm{F}$ (mother or father) and the ordinal numbers as the only marks used for the distinction of participants. The participants, who expressed their interest in research results, shared their e-mail addresses with the interviewer.

\section{Participants}

Total of eight participants took part in the semi-structured interviews and shared their views and interpretations of the experienced, accounting for their personal parenting situation (Carey, 2009). This study used the purposive sampling technique (Ritchie et al, 2013) as the key target were parents (five fathers and three mothers), which the researcher came in contact with during the course of humanitarian work at Caritas, Bulgaria. According to Milas (2005) when a portion of the observed population is for certain reasons more accessible or availa- ble to participate in the research, it may qualify as the appropriate sample. All participants voluntarily agreed to participate in the study. The details of the participants are presented in Table 1.

At the moment of interviewing, four of the participants were granted refugee status and subsidiary protection, while another four were still in the asylum procedure. Four participants were Syrian, three were Iraqi, and one participant was a Palestinian who had previously lived in Syria as a refugee. The age of the participants ranged from twenty-one to fifty-three. All were married except for one participant who was widowed. The number of their children ranged from one to five children. All fathers, and one mother, had been employed prior to their exile. Five participants claimed they wanted to stay and live in Bulgaria, while two participants indicated they wanted to stay only if they could secure employment, and one participant affirmed he preferred to return to Great Britain where he had already been granted the refugee status. One of the participants was readmitted with his family from Finland to Bulgaria in accordance with the Dublin Regulation.

Table 1

Participants' details

\begin{tabular}{|c|c|c|c|c|c|c|}
\hline $\begin{array}{l}\text { M- mother } \\
\text { F- father }\end{array}$ & $\begin{array}{l}\text { Country } \\
\text { of origin }\end{array}$ & Age & $\begin{array}{l}\text { Marital } \\
\text { status }\end{array}$ & $\begin{array}{c}\text { Number of children and } \\
\text { age }\end{array}$ & $\begin{array}{l}\text { Employment } \\
\text { before exile }\end{array}$ & Status \\
\hline M1 & $\begin{array}{l}\text { Palestine- } \\
\text { Syria }\end{array}$ & 48 & Widow & $\begin{array}{c}3 \text { children }(30,28 \text { and } \\
20 \text { years })\end{array}$ & No & $\begin{array}{l}\text { Subsidiary status } \\
\text { granted }\end{array}$ \\
\hline M2 & Syria & 26 & Married & 3 children $(4.5 ; 2$ and 1$)$ & No & Asylum seeker \\
\hline $\mathrm{F} 1$ & Syria & 37 & Married & $\begin{array}{c}2 \text { children (6.5 and } 1.5 \\
\text { years) }\end{array}$ & Yes & $\begin{array}{c}\text { Refugee status } \\
\text { granted }\end{array}$ \\
\hline $\mathrm{F} 2$ & Syria & 42 & Married & $\begin{array}{c}4 \text { children }(15,11,6,3 \\
\text { years })\end{array}$ & Yes & $\begin{array}{c}\text { Refugee status } \\
\text { granted }\end{array}$ \\
\hline F3 & Iraq & 34 & Married & 1 child (8 years) & Yes & Asylum seeker \\
\hline $\mathrm{F} 4$ & Syria & 21 & Married & 1 child (7 months) & Yes & Asylum seeker \\
\hline $\mathrm{F} 5$ & Iraq & 46 & Married & $\begin{array}{c}5 \text { children }(12,18,16,9, \\
1 \text { year and } 3 \text { months) }\end{array}$ & Yes & Asylum seeker \\
\hline M3 & Iraq & 53 & Married & 2 children $(31,25$ years $)$ & Yes & $\begin{array}{l}\text { Refugee status } \\
\text { granted }\end{array}$ \\
\hline
\end{tabular}


At the time of the interviews, four persons lived in the state administered refugee reception centre in Bulgaria, whilst the other four were privately accommodated. Majority (four fathers and two mothers) mentioned the fear for their children's safety being the main reason for flight. Only two participants (both mothers) mentioned being in contact with the rest of their family members in the country of origin, i.e., Syria.

\section{Data analysis}

A thematic analysis was used to analyse the collected data due to theoretically flexible approach (Brown and Clarke, 2008). On the one hand, thematic analysis has been viewed as a method which captures realistic, descriptive data, while on the other, it has been endorsed for its potential toward the systematic framework for coding of the qualitative data. We used it in this integrative manner due to its specificity to reveal the patterns as a result of data-driven and theory-driven analysis, well-suited for the small data sets (Taylor and Ussher, 2001)

Analysis of the data was organised according to the six steps (Braun and Clarke, 2006): 1) familiarisation with the data; 2 ) coding (semantic and conceptual reading of the data); 3) searching for themes (through similarities in the data coherent and meaningful patterns were identified); 4) reviewing the themes (ensuring that the data tell a compelling and convincing story); 5) defining and naming themes and 6) writing up of the key themes.

\section{RESULTS}

Data analysis yielded four dominant themes connected to the resilience vs vulnerability framework: 1) protective factors and support systems; 2) hopes and aspirations; 3) adversities of refugee experience and integration hardships; and 4) everyday psychosocial stresses. The first two thematic categories relate to resilience while the second two to vulnerability in parenting.

\section{Protective factors and support systems}

War and persecutions faced at home and a hope to bring their children to safety were central to accounts of parents in this research, thus revealing their strengths and determinations to survive and recreate better family conditions in a peaceful environment. However, the reality of post-flight adaptation, reception and integration to the Bulgarian environment is challenging. Thematic analysis of the protective factors and support systems available illustrates resources available to them. The overview is presented in the Table 2 .

Table 2

Protective factors and support systems identified by refugees in Bulgaria

\begin{tabular}{|c|c|}
\hline $\begin{array}{l}\text { Schooling of } \\
\text { children (2) }\end{array}$ & $\begin{array}{l}\text { 'Our children are going to school here } \\
\text { in the camp' (Mother, age 26, Syria) }\end{array}$ \\
\hline $\begin{array}{l}\text { Legal } \\
\text { entrance (3) }\end{array}$ & $\begin{array}{l}\text { 'There were no challenges, I didn't } \\
\text { come to Bulgaria illegally, I came legally, } \\
\text { I took visa, and came to Bulgaria...' } \\
\text { (Father, age 42, Syria) }\end{array}$ \\
\hline $\begin{array}{l}\text { Being } \\
\text { Christian (3) }\end{array}$ & $\begin{array}{l}\text { 'Also, for my family it is easy to live in } \\
\text { Bulgaria since we are Christian family, } \\
\text { so send boys and girls in the same } \\
\text { school for me it wasn't a problem... and } \\
\text { the holidays are the same holidays... } \\
\text { so I didn't miss much from my life' } \\
\text { (Mother, age 53, Iraq) }\end{array}$ \\
\hline $\begin{array}{l}\text { Small } \\
\text { expectations } \\
\text { (1) }\end{array}$ & $\begin{array}{l}\text { '...I don't think about something bigger, } \\
\text { I just want a safe place...' (Father, age } \\
\text { 37, Syria) }\end{array}$ \\
\hline $\begin{array}{l}\text { Strong family } \\
\text { ties (3) }\end{array}$ & $\begin{array}{l}\text { 'My wife... she is my heart...she loves } \\
\text { children...' (Father, age 46, Iraq) }\end{array}$ \\
\hline $\begin{array}{l}\text { NGOs } \\
\text { support (1) }\end{array}$ & $\begin{array}{l}\text { '...there are many NGOs for refugees, } \\
\text { to support them...to give information' } \\
\text { (Mother, age } 53, \text { Iraq) }\end{array}$ \\
\hline $\begin{array}{l}\text { Contact with } \\
\text { Bulgarian } \\
\text { children (1) }\end{array}$ & $\begin{array}{l}\text { '...it's easier to get integrated because } \\
\text { they are with other Bulgarian kids...' } \\
\text { (Mother, age } 53, \text { Iraq) }\end{array}$ \\
\hline Work (3) & $\begin{array}{l}\text { '...it's better to work to and have some } \\
\text { money than asking people for the money...' } \\
\text { (Mother, age 48, Palestinian Syrian) }\end{array}$ \\
\hline $\begin{array}{l}\text { Access } \\
\text { to health } \\
\text { services (1) }\end{array}$ & $\begin{array}{l}\text { 'So when she was in the hospital, } \\
\text { she used Kurdish translator and used } \\
\text { mobile phone and called UK. So she } \\
\text { called me and said, so this is what } \\
\text { happened. '(Father, age 34, Iraq) }\end{array}$ \\
\hline
\end{tabular}


Thematic analysis of interviews devoted to protective factors showed that there is a number of environmental factors involved in resilience of parents. They frequently referred to children's continued schooling, work, legal entrance to the country as well as children's contact with Bulgarian children and access to health services as beneficial to them. Other sociocultural support factors that were mentioned are strong family ties and being Christian which gave a sense of cultural familiarity to three of the families from Iraq and Syria. In terms of formal support services there was one mention of the NGO support as a significantly available protection factor. One parent's personal factor of being humble and having small expectations such as just being sheltered from war was mentioned as beneficial in the transitory situation of asylum reception centre.

\section{Hopes and aspirations}

Hopes of exiled parents center around normalisation of family's socio-economic, legal and psychological conditions, their children's education and aspirations for the better future. They are illustrated in the Table 3 below.

Aspirations for the better future primarily dependant on hope for regaining the safe home environment, finding employment and accessing refugee status for those in the asylum procedures. In fact, all 7 parents referred to safe housing conditions as their aspiration while school, employment and status were, in turn, all interconnected with aspirations to renormalise life after the shattering war experiences in an environment which lends little socio-economic opportunities for integration.
Table 3

Hopes and aspirations of refugees in Bulgaria

'I hope we will get status and that we will have normal life here... or try to have normal life somewhere else... (Mother, age 26, Syria)

Normalisation of I want to see my children life (4) happy' (Mother, age 48, Palestine) 'I hope I will come back to my life like before and see myself as human being.' (Father, age 37, Syria)

\begin{tabular}{|c|c|}
\hline $\begin{array}{l}\text { Refugee status } \\
\text { (4) }\end{array}$ & $\begin{array}{l}\text { 'My biggest hope is to get } 5 \\
\text { years status so I can go to } \\
\text { try to some another country } \\
\text { where I can get better } \\
\text { insurance...' (Father, age 21, } \\
\text { Syria) }\end{array}$ \\
\hline Employment (1) & $\begin{array}{l}\text { '... that all my children will } \\
\text { have their work (job)'. (Mother, } \\
\text { age } 48 \text {, Palestine) }\end{array}$ \\
\hline Safe housing (7) & $\begin{array}{l}\text { 'I hope to buy a house and } \\
\text { I hope the money that I give } \\
\text { now for my rent I will put in } \\
\text { my pocket,... because it's very } \\
\text { difficult'. (Father, age 42, Syria) } \\
\text { 'It's a small hope. Only small } \\
\text { house and a simple life with } \\
\text { my family... No problem } \\
\text { here or in another country...' } \\
\text { (Father, age 46, Iraq) }\end{array}$ \\
\hline School (5) & $\begin{array}{l}\text { 'I want that my children go } \\
\text { to school and have a future... } \\
\text { (Mother, age 26, Syria) } \\
\text { 'All children have to go to } \\
\text { school... and then they come } \\
\text { back home and talk everything } \\
\text { they did in the school... } \\
\text { (Father, age 46, Iraq) }\end{array}$ \\
\hline
\end{tabular}

\section{Adversities of refugee experience and integration hardships}

Adversities of parents related to actual refugee experience but also asylum procedures and integration challenges are many. Refugees interviewed have accounted for various environmental factors and the overview of these as dominant themes found in this analytic data category are presented in Table 4. 
Table 4

Adversities and hardships of refugees in Bulgaria

\begin{tabular}{|c|c|}
\hline Themes & Examples \\
\hline $\begin{array}{l}\text { Deaths and } \\
\text { bereavement } \\
\text { processes (5) }\end{array}$ & $\begin{array}{l}\text { 'My brother and his wife and } 4 \text { children and my sister and my cousin with their } 3 \\
\text { children, they came from Iraq, they tried to come to Bulgaria to apply for an asy- } \\
\text { lum, but on the way, my brother and my cousin, they have died in a snow. So my } \\
\text { brother's wife, my sister in law, she died in hospital in Bulgaria' (Father, age 34, Iraq) } \\
\text { 'I lost my husband and my house in Syria...' (Mother, age 48, Palestinian Syrian) }\end{array}$ \\
\hline $\begin{array}{l}\text { Flight and arduous } \\
\text { journey to Bulgaria (5) }\end{array}$ & $\begin{array}{l}\text { 'Journey was very hard. It was snow, it was very cold, we were freezing and they } \\
\text { (children) were sleeping in the snow.' (Mother, age 26, Syria) }\end{array}$ \\
\hline $\begin{array}{l}\text { Health issues (physical } \\
\text { and mental health) (3) }\end{array}$ & $\begin{array}{l}\text { 'I almost died... first year here in Bulgaria my children were afraid of airplane, } \\
\text { every time they hear airplane they started to cry because they remembered... } \\
\text { they are still afraid...' (Father, age 37, Syria) }\end{array}$ \\
\hline Unemployment (8) & $\begin{array}{l}\text { 'All refugees... they don't have chance to find job here...' (Father, age } 46 \text {, Iraq) } \\
\text { 'Here, you can't find a work and my family is a big family and I must ... we must } \\
\text { to work...' (Father, age 46, Iraq) } \\
\text { 'If kids go to school you need money... so here I don't work, so who is going to } \\
\text { pay for the school, bus, food?' (Father, age 34, Iraq) }\end{array}$ \\
\hline $\begin{array}{l}\text { Difficulties of } \\
\text { accommodations and } \\
\text { poor living conditions } \\
\text { (5) }\end{array}$ & $\begin{array}{l}\text { '...because in Syria I had the house... and now I came here to rent a flat and live } \\
\text { in a small house/flat... it's very hard for us....' (Father, age 37, Syria) }\end{array}$ \\
\hline $\begin{array}{l}\text { Limited access to } \\
\text { schooling of children } \\
\text { (6) }\end{array}$ & $\begin{array}{l}\text { 'Sometimes I think about... now, I cannot go back to my country... because I } \\
\text { have problems... but my children, they don't have anything... why they had to } \\
\text { run from my country to here? And now they don't have school... all children have } \\
\text { to go to school...' (Father, age 46, Iraq) }\end{array}$ \\
\hline $\begin{array}{l}\text { Livelihood difficulties } \\
\text { (8) }\end{array}$ & $\begin{array}{l}\text { 'Bulgarian government is not supporting us with the money but at least they are } \\
\text { supporting us with documents, and they gave to us second chance, for me and } \\
\text { my family- to live better' (Father, age 42, Syria) }\end{array}$ \\
\hline $\begin{array}{l}\text { Lack of formal } \\
\text { integration } \\
\text { programmes (3) }\end{array}$ & $\begin{array}{l}\text { 'So the challenges are how to make daily living.....and here there is no programme } \\
\text { of social integration from the government, so we rely on NGO's or campaigns...' } \\
\text { (Mother, age 53, Iraq) }\end{array}$ \\
\hline
\end{tabular}

Five persons referred to personal losses including those of close family members, relatives and extended family either during flight period or in the host country now going through bereavement process. Stressful flight conditions and reaching the Bulgarian border were experienced by half of them with direct effects on physical and mental health of both children and themselves.

During the reception and integration phase, all eight of interviewees have reported unemployment and struggle with the livelihood. Connected to this are poor living conditions of five informants and limited access to schooling of the children reported by another six due to shortage of personal identification documents required for accessing the education system.

Other research has pointed to the fact that despite formal access to employment as a provision in domestic law for asylum seekers and refugees in Bulgaria, many structural barriers prevent them from accessing the labour market, thus leading to discrimination, exclusion and marginalization (see Hajdinak, 2011). Finally, it is clear that lack of systemic integration programmes affects all presented challenges of post-flight adaptation even though only three parents were able to vocalise and directly reflect on this in the interviews. 


\section{Everyday psychosocial stresses}

Apart from environmental factors there are also individual ones which make refugee parents particularly vulnerable during the period of acquiring asylum, settling down and integrating to the Bulgarian society. The overview of these psychosocial stresses is presented in Table 5.

Table 5

Psychosocial stresses encountered by refugees in Bulgaria

\begin{tabular}{|c|c|}
\hline Themes & Examples \\
\hline $\begin{array}{l}\text { Sheltering children } \\
\text { from war and desire for } \\
\text { safety and prosperous } \\
\text { future of children in } \\
\text { exile (8) }\end{array}$ & $\begin{array}{l}\text { '...and when the war escalated, we fled only with the clothes on our back... We } \\
\text { were afraid for our children's lives... We escaped and we just want to be in a } \\
\text { safe place. We escaped for our children's future...' } \\
\text { (Mother, age 26, Syria) }\end{array}$ \\
\hline
\end{tabular}

War trauma among children (4)

'they hear airplane they start to cry because they remembered... they are still afraid... till now we can't find solution for her (daughter) when she hears sound of airplane... we can't ever leave her alone...' (Father, age 37, Syria)

'I was afraid how to send them to school and how they will learn this language' (Father, age 42, Syria)

Anxiety due to inability 'When I am thinking of my child future... the hardest is how I will ensure that my of children to access education (7) baby will have good education...' (Father, age 21, Syria) 'And now they do not have school... they don't have any time to see their friends... or to go to see/watch something funny to them...' (Father, age 45, Iraq)

'Well, everything is hard... my daughter is in UK, my wife in Iraq, 7 children in Bulgaria ... my mother still in Iraq...' (Father, age 34, Iraq)

Family separations and '.. and also, we are thinking about our family who are still in Syria and trying to guilt feelings (3) make some solution, maybe we can help the rest of our family.' (Mother, age 26, Syria)

'...everything I had to do by myself... so... and I tried to find a courage to stay Loneliness and social here...' (Mother, age 53, Iraq)

isolation (5)

'...but we don't see anyone helping us...we don't see anyone in general...' (Father, age 46, Iraq))

'[The hardest thing is]... The language because I am not young, I cannot understand everything and Bulgarian language is very difficult for me' (Mother,

Language barriers (8) age 48, Palestinian-Syrian)

'The language... they [Bulgarians]... don't speak English' (Father, age 34, Iraq) '

Psychotrauma in parents (5) 'We saw many hard things... sometimes when I remember those things I want to cry, but I don't want to cry in front of my family...' (Father, age 46, Iraq)

'It's very very hard... you have to take care about your house, your wife, your children, too much pressure, you kill yourself...' (Father, age 34, Iraq)

Livelihood stresses (5) 'If you have money you are fine here but if you don't, it's very very hard...' (Father, age 34, Iraq)

Uncertainty for their future (8)
'It's very difficult. Before we didn't have to think about future because we had everything and now we lose everything and we needed to start again... like a person with clothes and next day without clothes... how is it to be? Big change...' (Father, age 37, Syria) 
Parents' fear for the lives of their children during war and hostilities in Syria and Iraq was a mentioned as a main trigger of their flights. All eight accounted that they decided to flee their country solely for concerns over the safety of their children. These fears and anxieties make them particularly vulnerable as their expectations of exile conditions rest on conviction of better future for their children. One parent explained how he lived in war circumstances for three years and faced life-threatening situations on four occasions, yet he decided to leave only when his children faced direct life threats. Half of the parents mentioned recurrent traumatisation in their children caused by environmental stimuli, like sharp sounds. Majority however, pointed to persistent concerns and fears they have regarding the inability of children to continue the schooling and normalise their lives after these traumas. Typically, three of parents mentioned separations from close and extended family members and relatives left behind in Syria and Iraq causing feelings of a survival guilt. They have also endured personal traumas due to war, losses and reaching Bulgaria. On top of these experiences they face social isolation and loneliness directly connected to the language barrier all eight have reported. Economic hardships are part of their everyday reality in Bulgaria. Hence, all fear for their future and describe uncertainty as a dominant psychological burden.

\section{DISCUSSION AND IMPLICATIONS}

According to the United Nations High Commissioner for Refugees, the prolonged period of exile, which entails the unremitting feeling of uncertainty for refugees and their families in circumstances that are no longer life-threatening, may, in fact, result in their inability to access basic rights and satisfy their economic, social and psychological needs.
Indeed, the literature focusing refugee rights speaks abundantly about such violations and challenges pointing to devastating socio-economic and psychological effects during various phases of exile (see e.g. Verdirame \& Harrell-Bond, 2005; Rubio-Marin 2014; O’Sullivan\& Stevens, 2017; Porobić \& Blitz; 2018, Porobić, 2018, 2017, 2016, 2012). In addition, it is a well-documented fact that refugee children are particularly exposed to the great number of vulnerabilities across the refugee process and that the role of parents as care givers is crucial for their wellbeing in the transitory exile situation (see e.g. Hancheva, 2018; Garin, Beise, Hug \&You, 2016; Hynie, Guruge and Shakya, 2012; Melzak, 1999).

The principal push factor for families in this research, all affected by war and hostilities in Syria and Iraq, was to protect their children by providing a safe environment and enable education and stability. Their experiences during and after asylum procedures in Bulgaria demonstrate various vulnerability factors in their parenting and family life that outweigh the available resilience sources. The protective factors that we identified were both environmental like children's continued schooling, work, legal entrance to the country as well as children's contact with Bulgarian children and access to health services, strong family ties, being Christian and NGO support as a significantly available resources. Majority of parents referred to safe housing conditions as their hopes, while school, employment and status were, in turn, all interconnected with aspirations to renormalise family life after the shattering war experiences.

However, the vulnerabilities were by far greater than these protective resources. It is clear that the causes of these vulnerabilities are systemic failures i.e. mesofactors like long-standing asylum procedures, pressure of rejection due to high rejection rates and formal shortcomings of the asylum system. 
Similarly, for refugee parents these involve lack of integration support programs resulting in poor housing, lack of employment, lack of education for children and inability to access social protection services. In general, the results of this research clearly point to direct impact of shortcomings of the protection system in Bulgaria on the vulnerabilities of parents in exile, while resilience factors remain rather random and unsystematic. The explications of such analysis are offered in further detail below by particularly discussing the asylum procedures and integration programs systemic shortcomings.

\section{Systemic shortcomings in refugee protection causing vulnerability}

\section{A) Asylum procedures}

UNHCR has observed that with the rise in number of refugees who arrived to Bulgaria during 2014-2016, the shortcomings of the asylum system have only proliferated, which has seriously affected the most vulnerable groups (UNHCR, 2014a). Our group of parents interviewed thus witnessed long-standing asylum procedures exerting great pressure on their every-day lives especially affecting active parenting and ability to plan their future life goals including children's continued education.

In terms of accommodation, the Bulgarian Law on Asylum and Refugees stipulates that applicants for international protection have the right to accommodation in reception centres or in alternative arrangement while their application is being processed, with special consideration to their health condition, family and financial status (Law on Asylum and Refugees, 2005). The interviewed parents witnessed about the shortcomings of such protective considerations in reality. They were rather exposed to inhuman and degrading treatment as a result of the systematic shortcomings during processing of asylum applications in the reception centre (see even UNHCR, 2014a).

Due to his fact, despite the formal recognition of asylum right and refugee protection, in reality, the refugees in Bulgaria remain profoundly marginalized. Instead of being assisted and supported by means of social protection programs, based on a comprehensive policy framework for integration and employment, they remain excluded from the society. Moreover, it has been noted in earlier research and NGO reports that the Ministry of Labour and Social Policy in Bulgaria, in fact, does not include the refugees on the list of vulnerable groups entitled to welfare benefits (Hajdinak, 2011; AIDA, 2015b).

In addition, the Bulgarian authorities provide minimal or no financial support to refugees who have been granted refugee status or who leave reception centres, while the European Union limits labour opportunities for refugees who have been granted asylum in one member state to work in other member states of the EU, which makes the refugee experience even more difficult in Bulgaria. Even the monthly allowance for refugees based on the minimal financial assistance of $€ 33.23$ per month both for children and adults has been declared insufficient for meeting the basic needs (UNHCR, 2014, AIDA, 2016). Furthermore, in 2016 State Agency for Refugees in Bulgaria discontinued the minimal monthly allowance to asylum seekers in refugee centres (European Council on Refugee and Exiles, 2016). In view of this and inadequate living conditions of asylum seekers in Bulgaria, the European Council on Refugees and Exiles continuously calls for termination of EU financial assistance to Bulgaria.

Besides lack of formal social protection assistance during the asylum procedures and after receiving the status thus resulting in ultimate poverty, refugee parents frequently encounter language barriers 
which further impede on their own ability to counter the hardships of unemployment, lack of access to education for children, lack of access to adequate health care and housing. The vulnerabilities caused by the fallacy of the system due to no social protection and lack of integration provisions clearly have a direct bearing on parenting conditions with a negative outcomes and impact on the basic stability of the family in exile.

\section{B) Lack of integration programmes}

According to the official AIDA (2016) reports, no integration programs have been established so as to ensure successful social inclusion of refugees, and the period from 2014 to 2015 is referred to as "years of zero integration". Two years after the adoption of the National Program for the Integration of Refugees in 2005, the beneficiaries of international protection have lost all mechanisms of support for integration. As evidenced by our research this resulted in direct limitations in accessing to basic social protection rights and reduced a number of refugees who expressed the intent to stay in Bulgaria to the minimum. The adversities and hardships in integration to the Bulgarian society as recorded in the accounts of our informants stem directly from these legal, social, cultural and economic hindrances in accessing work, education, health care including psychosocial support for endured war and refuge traumas.

Majority of parents described lack of employment and income as the greatest adversity encountered impacting overall family life including children's schooling and health care for families. The position of the Bulgarian government is that integration programs should not impose additional pressures on the labour market. This translates into the attitude that refugees should be offered employment only in areas with labour deficit, such as the textile industry or construction. Moreover, the jurisdiction over the social integration of refugees is still being disputed among the Ministry of the Interior and the Ministry of Labour and Social Welfare (EESC, 2016). In addition, there are no independent bodies charged with the development and the implementation of a clear policy on migration, which creates further confusion and uncertainty among the refugees, as well as the professional community and the state administration (Hajdinak, 2011).

Refugee families, reconstructing their lives in Bulgaria, need to acquire sufficient language competences to be able to access the socio-economic rights like other citizens and integrate in their new environment. Language barriers and no introductory language courses or interpreters were clearly pointed out as vulnerability. In 2016, the Bulgarian authorities received 2 million EUR from the EU fund for the implementation of integration activities over the next seven-year period, with vulnerable groups as the final beneficiaries of the allocation (EESC, 2016). Moreover, unlike Germany, Bulgaria has not foreseen the provision of language courses, while the investment in language training represents the key prerequisite for the integration of refugees who stay in Bulgaria (EESC, 2016).

The language barrier represents a common personal challenge for parents who settle in a new community and culture. If they experience additional environmental constraints of the kind in Bulgaria, it is likely that parents feel demoralized and socially isolated (see e.g. Yako and Biswas, 2014).

Until now, the priorities of the government did not acknowledge the gravity of the situation and the emerging need of refugees and migrants. In the long run, the inadequate legal and institutional framework for the integration of refugees may result in their frustrations over the oppression, alienation and protracted subaltern position. At the same time, the prolifera- 
tion of xenophobia among the Bulgarian population is growing and deepening the marginalization and the social isolation of refugees (Hajdinak, 2011).

\section{Implications for service providers and practioners}

To sum up, the vulnerabilities rooted in the disadvantaged socioeconomic position of refugee parents in Bulgaria resulting from violation of refugees' protection and basic human rights have led to subaltern and disempowering position of refugee families. These inhumane and degrading treatments as a result of inefficient asylum system that frequently violates the rights of refugees, both during the asylum procedures and later after status recognition hindering full integration into the host society, have had wide implications for the identified vulnerabilities of the parents interviewed in this research.

These results have also implications for the helping professions in Bulgaria. Here, we would call an attention to mental health practitioners and social workers together addressing such gross violations through means of methods available for psychosocial support drawing from their own professional imperatives. Regular psychosocial support to parents significantly contributes to helping children in crisis situations (Pezerović, Milić-Babić, 2016). The importance of family on the one hand, and the prevention of recurrent exposure to stress and trauma on the other, may be observed in the support services to parents aimed at the enhancement of their parental skills (Norris, Fiedman and Watson, 2002; Pezerović and Milić-Babić, 2016). On the other hand, benefit of using group counselling is that it can alleviate the sense of isolation many refugees during the acculturation process, and offer a support network within the group as well as create a safe place for refugee parents in particular (Asner-Seif and Feyissa, 2002).
Finally, as a general recommendation we believe that the only way forward is to work towards full access to protection rights and social inclusion of refugees in Bulgaria. Well-structured programs of social protection, including enhanced mechanisms for post-flight adaptation within the reception and integration program framework, should be immediately addressed by international and national non-state actors involved in the refugee services in Bulgaria. We further recommend the inclusion of social work and mental health professions in ameliorating stresses of exclusion and advancing the integration rights and social position of refugee families.

\section{Declaration of Conflicting Interests}

The authors declared no potential conflicts of interest with respect to the research, authorship, and/or publication of this article.

\section{REFERENCES}

Aleksandrova, B. (2014). On a pathway to a global society? The role of states in times of global migration - Implications for Bulgaria's handling of syrian refugees (2013-2014). Turkish Journal of International Relations, 13(4), 29-40. https://doi. org/10.21599/atjir.04176

Allen, J., Vaage, A., \& Hauff, E. (2006). Refugees and asylum seekers in societies. In D. L. Sam \& J. W. Berry (Eds.), The Cambridge handbook of acculturation psychology (pp. 198-207). Cambridge: Cambridge University Press.

Almquist, K., \& Broberg, A.G., (1999). Mental health and social adjustment in young refugee children 3 and half years after their arrival in Sweden. Journal of American Academy of Child \& Adolescent Psychiatry, 38(6),723-730. https://doi. org/10.1177/1359104512462549

Asner-Seif, K., \& Feyissa, A. (2002). The use of poetry in psychoeducational groups with multicultural-multilingual clients. Journal for Specialists in Group Work, 27(2), 136-160. https:// doi.org/10.1177/0193392202027002003

Asylum Information Database. (2015). Country report - Bulgaria. Available at http://www.asylumineurope.org/sites/default/files/report-download/ aida_bg_update.iv_.pdf 
Asylum Information Database. (2016). Regular Procedure - Bulgaria. Available at http://www.asylumineurope.org/reports/country/Bulgaria/asylum-procedure/procedures/ regular-procedure

Birman, D., Ho, J., Pulley, E., Batia, K., Everson, M.L., Ellia, H., Stichick- Betancourt, T., \& Gonzalez, A. (2005). Mental health interventions for refugee children in resettlement: White paper II. Los Angeles: National Child Traumatic Stress Network.

Bulgarian Helsinki Committee. (2016). Human rights in Bulgaria in 2015: Annual report of the Bulgarian Helsinki Committee. Available at http://www.bghelsinki.org/media/uploads/ annual_reports/annual_bhc_report_2015_issn2367-6930_en.pdf

Driscoll, A., Russell, S., \& Crockett, L. (2008). Parenting styles and youth well-being across immigrant generations. Journal of Family Issues, 29(2), 185210. https://doi.org/10.1177/0192513X07307843

European Council on Refugees and Exiles. (2016). Reception conditions, detention and procedural safeguards for asylum seekers and content of international protection status in Bulgaria. Avaialble at http://www.asylumlawdatabase.eu/ sites/ www.asylumlawdatabase.eu/files/aldfiles/ Research\%20Note\%20-\%20Reception\%20conditions, $\% 20$ detention $\% 20$ and $\% 20$ procedural $\% 20$ safeguards $\% 20$ for $\% 20$ asylum $\% 20$ seekers $\% 20$ and $\% 20$ content $\% 20$ of $\% 20$ international $\% 20$ protection\%20status\%20in\%20Bulgaria.pdf

European Economic and Social Committee. (2016). EESC fact-finding missions on the situation of refugees, as seen by civil society organisation: mission report - Bulgaria. Available at http:// www.eesc.europa.eu/resources/docs/bulgaria migration-mission-report_en.pdf

Eurostat. (2016). Population on 1 January - persons. Available at http://ec.europa.eu/eurostat/tgm/ table.do?tab=table \&plugin=1\&language=en \&pcode $=$ tps00001

Fatumo, O., Allvin, M. K., Flacking, R., \& Schön, U. K. (2016). Somali-born parents' experiences and needs for parenting support programmes. International Health and Human Rights, 16(7), 1-11. https://doi.org/10.1186/s12914-016-0082-2

Fazel, M., \& Stein, A. (2002). The mental health of refugee children. Archives of disease in Childhood, 87(5), 366-370. https://doi.org/10.1136/adc.87.5.366

Garin, E., Beise, J. Hug, L., \& You, D. (2016). Uprooted: The growing crisis for refugee and migrant children. Paris: UNICEF.

George, M. (2009). Sri Lankan Tamil diaspora: Contextualizing pre-migration and post-migration traumatic events and psychological distress. Toronto: University of Toronto Press.

Gillham, B. (2005). Research Interviewing: The Range of Techniques. London: Open University Press.

Groves, B., \& Zuckerman, B. (1997). Interventions with parents and caregivers of children who are exposed to violence. In J. D. Osofsky (Ed.), Children in a violent society (pp. 183-201). New York: Guilford.

Hancheva, C., (2018). Child refugee: transition, migration and transitional. In A. Hamburger, S. Tutnjevic, C. Hancheva, S. Ozcurumez, B. Stankovic \& C. Scher (Eds.), Migration and Social Trauma: Interdisciplinary Perspectives (pp. 148158). London: Routledge.

Hynie, M., Guruge, S., \& Shakya, B. Y. (2012). Family Relationships of Afghan, Karen and Sudanese Refugee Youth. Canadian Ethnic Studies, 44(3), 11-28. https://doi.org/10.1353/ces.2013.0011

International Organization for Migration. (2016). Mixed Migration Flows in the Mediterranean and beyond: Compilation of available data and information. Available at http://reliefweb.int/sites/reliefweb.int/files/ resources/mixed-flows-mediterranean-and-beyond-21-27-january-2016.pdf

Kerig, P. K. (2018). Refugee children and their parents. Journal of Traumatic stress. Virtual Special Issue.

Kirmayer, L., Narasiah, L., Munoz, M., Ryder, A. G., Guzder, J., Hassan, G., Rousseau, C., \& Pottie, K. (2011). Common mental health problems in immigrants and refugees: general approach in primary care. Canadian Medical Association Journal, 183(12), 959-967. https://doi. org/10.1503/cmaj.090292

Kwak, K. (2003). Adolescents and their parents: A review of intergenerational family relations for immigrant and non-immigrant families. $\mathrm{Hu}$ man Development, 46(2-3), 15-136. https://doi. org/10.1159/000068581

Lalić-Novak, G., \& Kraljević, R. (2014). Zaštita izbjeglica $i$ ranjivih skupina migranata. Zagreb: Hrvatski Crveni križ.

Landale, S. N., Thomas, K .J., \& Van-Hook, J. (2011). The living arrangements of children of immigrants. Future Child, 2(1), 43-70. https://doi. org/10.1353/foc.2011.0003

Melzak, S., (1999). Psychotherapeutic work with children and adolescent refugees from political violence. In M. Lanydo \& A. Horne (Eds.), The Handbook of Child and Adolescent Psychotherapy. London: Routledge. 
Milas, G. (2009). Istraživačke metode u psihologiji i drugim društvenim znanostima. Jastrebarsko: Naklada Slap.

Milenković, T., Simonović, M., Samardžić, L., Nikolić, G., Grbeša, G., \& Stanković, M. (2010). Impact of social support on severity of posttraumatic stress disorder. Acta Medica Medianae, 49(4), 31-35.

Miller, K. E., \& Rasmussen, A. (2010). War exposure, daily stressors, and mental health in conflict and post-conflict settings: Bridging the divide between trauma-focused and psychosocial frameworks. Social Science \& Medicine, 70(1), 7-16. https://doi.org/10.1016/j.socscimed.2009.09.029

Nazarska, G. Mancheva, N., Troeva, E., \& Hajdinjak, M. (2011). Migrations, gender and intercultural interactions in Bulgaria. Sofia: International Center for Minority Studies and Intercultural Relations.

Nesteruk, O., \& Marks, D. L. (2011). Parenting in immigration: Experiences of mothers and fathers from Eastern Europe raising children in the United States. Journal of Comparative Family Studies, 42(6), 809-825. https://doi. org/10.2307/41604491

Norris, F. H., Friedman, M. J., \& Watson, P. J. (2002). 60,000 disaster victims speak: Part II. Summary and implications of the disaster mental health research. Psychiatry, 65(3), 240-260. https://doi. org/10.1521/psyc.65.3.207.20173

Öner-Şirin, A. N. (2015). Social integration of forced migrants: The case of 1989 emigrees from Bulgaria in Tekirdag. History Research, 5(1), 45-60. https://doi.org/10.17265/2159-550X/2015.01.004

Osofsky, J. D., \& Fenichel, E. (1994). Hurt, healing, and hope: Caring for infants and toddlers in violent environments. Zero to Three Bulletin. Arlington, VA: National Center for Clinical Infant Programs.

Osofsky, J. D., \& Fenichel, E. (1996). Islands of safety: Assessing and treating young victims of violence. Zero to Three Bulletin. Washington, DC: Zero to Three, National Center for Infants, Toddlers, and Families.

Osofsky, J. D., \& Fenichel, E. (2000). Protecting young children in violent environments. Zero to Three Bulletin. Washington, DC: Zero to Three, National Center for Infants, Toddlers, and Families.

Pezerović, A., \& Milić Babić, M. (2016). The importance of counselling work for refugee children. Ljetopis socijalnog rada, 23(3), 363-380. https:// doi.org/10.3935/ljsr.v23i3.113
Porobić, S. (2012). Resilience and religion in a Forced Migration Context. Lund: Lund University.

Porobić, S., (2015). Asking the right questions in research on psychosocial well-being. Forced Migration Review, (50).

Porobić, S. (Ur.). (2016a). Rodna studija prisilne migracije i dobrostanja u Bosni i Hercegovini. Sarajevo: Fondacija za osnaživanje žena BiH.

Porobić, S. (2016b). Daring 'life-return projects' to post-Dayton Bosnia and Herzegovina. International Migration, 55(5), 192-204. https://doi. org/10.1111/imig.12366

Porobić, S. (2017). Invisible returns of former Bosnian refugees and sociality of their well-being. In R. King \& Z. Vathi (Eds.), Return Migration and Psychosocial Wellbeing: Discourses, Policy-Making and Outcomes for Migrants and their Families (pp. 108-126). London: Routledge.

Porobić, S. (2018). How can refugees heal? Reflections on healing practices across the refugee process: From displacement to integration, return and beyond. In A. Hamburger, S. Tutnjević, C. Hancheva, S. Ozcurumez, B. Stanković \& C. Scher (Eds.), Migration and Social Trauma: Interdisciplinary Perspectives (pp. 105-115) London: Routledge.

Porobić, S., \& Blitz, B. (Eds.). (2018). Forced migration, gender and wellbeing: The long term effects of war and displacement on women. London: Edward Elgar.

Rogers, C. H., Floyd, F. J., Seltzer, M., Greenberg, J., \& Hong, J. (2008). Long-Term Effects of the Death of a Child on Parents' Adjustment in Midlife. Journal of Family Psychology, 22(2), 203211. https://doi.org/10.1037/0893-3200.22.2.203

Ruth, R. M. (2014). Human Rights and Immigration. Oxford: Oxford University Press.

State Agency for Refugees. (2018). Information for asylum seekers and decisions taken 01.01.1993 - 31.01.2018. Available at http://www.aref.government.bg/index.php/en/statistics-and-reports

Supple, A., \& Small, S. (2006). The influence of parental support, knowledge and authoritative parenting on Hmong and European American adolescent development. Journal of Family Issues, 27(9), 1214-1232. https://doi. org/10.1177/0192513X06289063

Teoderescu, S., Heir, T., Hauff, E., Wentzel-Larsen, T., \& Lien, L. (2012). Mental health problems and post-migration stress among multitraumatized refugees attending outpatient clinics upon resettlement to Norway. Scandinavian Journal of Psychology, 53(4), 316-332. https://doi.org/10 $.1111 /$ j.1467-9450.2012.00954 
Tingvold, L., Hauff, E., Allen, J., \& Middelthon, A. L. (2012). Seeking balance between the past and the present: Vietnamese refugee parenting practices and adolescent well-being. International Journal of Intercultural Relations, 36(4), 563-574. https:// doi.org/10.1016/j.ijintrel.2012.03.004

United Nations High Commissioner for Refugees. (1951). Konvencija i protokol o statusu izbjeglica. Geneva: UNHCR.

United Nations High Commissioner for Refugees. (2006). The State of The World's Refugees 2006: Human Displacement in the New Millennium. Available at http://www.unhcr.org/ publications/sowr/4a4dcla89/state-worlds-refugees-2006-human-displacement-new-millennium.html

United Nations High Commissioner for Refugees. (2014a). Bulgaria as a country of asylum. Available at http://www.refworld.org/pdfid/52c598354.pdf

United Nations High Commissioner for Refugees. (2014b). Bulgaria as a country of asy- lum. Available at http://www.refworld.org/docid/534cd85b4.html

United Nations High Commissioner for Refugees. (2016a). Global Trends: Forced displacement in 2015. Available at http://www.unher. org/576408cd

United Nations High Commissioner for Refugees (2016b). Europe's refugee emergency response update \#27. Available at http://reliefweb.int/ sites/reliefweb.int/files/resources/ EuropeRefugeeEmergencyResponse-Update\%2327.pdf

Valle, P. (2001). Traumatized refugee children. Miami, FL: Florida International University.

Verdirame, G., \& Harrell-Bond, B. (2005). Rights in exile: Janus-faced humanitarianism. New York: Berghahn Books.

Yako, M. R., \& Biswas, B. (2014). We came to this country for the future of our children. We have no future: Acculturative stress among Iraqi refugees in the United States. International Journal of Intercultural Relations, 38(4), 133-141. https:// doi.org/10.1016/j.ijintrel.2013.08.003 
Sažetak

\title{
RODITELJI U EGZILU: IZAZOVI RODITELJSTVA MEĐU IZBJEGLICAMA I TRAŽITELJIMA AZILA U BUGARSKOJ
}

\author{
Alma Pezerović \\ Save the Children International \\ Hrvatska \\ Marina Milić Babić \\ Studijski centar socijalnog rada \\ Pravni fakultet Sveučilišta u Zagrebu \\ Zagreb, Hrvatska \\ Selma Porobić \\ Palacký University Olomouc \\ Olomouc, Czech Republic
}

Cilj: U radu se analiziraju iskustva roditelja izbjeglica s ciljem prikazivanja izazova roditeljstva tijekom i nakon traženja azila u Bugarskoj-zemlje smještene na dnu ljestvice odobravanja zahtjeva za azil u Europi. Metode: Kvalitativno istraživanje putem polustrukturiranih intervjua s osam roditelja podrijetlom iz Iraka, Sirije i Palestine provedeno je tijekom tromjesečnog razdoblja u 2016. godini. Rezultati: Provedeno empirijsko istraživanje pokazalo je da proceduralni nedostatci u sustavu zaštite izbjeglica u Bugarskoj uzrokuju težak psihosocijalni stres obiteljima, jer čimbenici kao što su spori i manjkavi postupci vezani uz dobivanje azila, nedovoljna razina socijalne zaštite i nedostatak integracijskih programa imaju izravan učinak na obiteljski život, roditeljstvo i dobrobit djeteta. Rasprava: Ovi rezultati ukazuju na jasnu potrebu za poboljšanjem u ostvarivanju prava na azil $i$ kasnijoj integraciji izbjeglica u Bugarskoj. Rezultati isto tako traže sustavni pristup kojim bi se prava izbjeglica poštivala u potpunosti $i$ kojim bi se ispravno pristupilo liminalnom položaju roditelja izbjeglica. Nadalje preporučamo intervencije profesija socijalnog rada i mentalnog zdravlja kako bi se ublažio postojeći stres povezan s isključenošću i marginalizacijom izbjegličkih obitelji u cilju promicanja njihovih integracijskih prava.

Ključne riječi: zaštita izbjeglica, pravo na azil, integracija, izbjegličke obitelji, roditeljstvo u egzilu, psihosocijalna podrška 